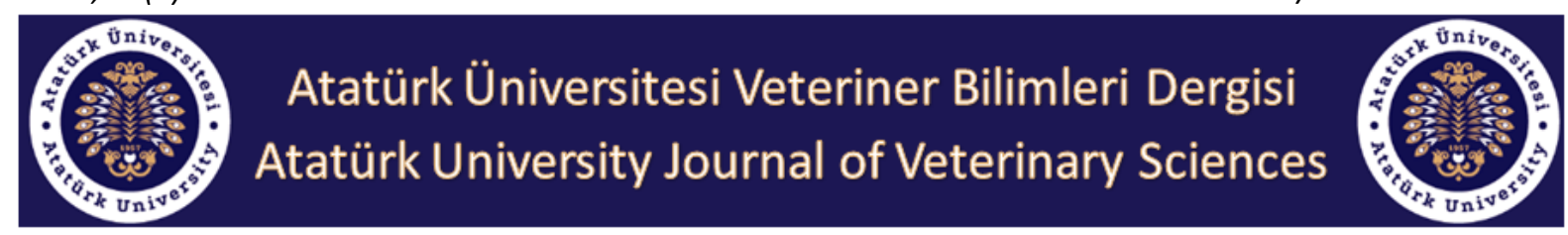

\title{
Brusella ile Enfekte Koyunlarda Haptoglobin ve Serum Amiloid A Düzeyinin Belirlenmesi*
}

\section{Hatice Gizem BÜYÜKBAKi ${ }^{1 a}$, Kadir BOZUKLUHAN²bه*}

1. Kafkas Üniversitesi, Sağlık Bilimleri Enstitüsü, Kars, TÜRKiYE.

2. Kafkas Üniversitesi, Kars Meslek Yüksekokulu, Kars, TÜRKIYE. ORCID: 0000-0002-9627-6137ª ,0000-0003-4929-5156 ${ }^{\text {b }}$

\begin{abstract}
Geliş Tarihi/Received
Kabul Tarihi/Accepted

Yayın Tarihi/Published

01.12 .2020

20.03.2021

31.10.2021

Bu makaleye atıfta bulunmak için/To cite this article:

Büyükbaki HG, Bozukluhan K: Brusella ile Enfekte Koyunlarda Haptoglobin ve Serum Amiloid A Düzeyinin Belirlenmesi. Atatürk Üniversitesi Vet. Bil. Derg., 16(2): 164-169, 2021. DOI: 10.17094/ataunivbd.834349

Öz: Brusellozis birçok evcil ve yabani hayvanı etkileyen uterus, meme, testis gibi genital organlara yerleşerek süt veriminde azalma, yavru atma ve infertiliteye neden olan, kronik seyirli zoonoz bir hastalıktır. Yangı, doku hasarı ve brusella gibi enfeksiyonlarda karaciğer tarafından sentezlenen akut faz proteinler (AFP) teşhis, tedavinin izlenmesi ve prognozun değerlendirilmesinde kullanılmaktadır. Bu nedenle çalışma brusellozisli koyunlarda, bazı AFP ve biyokimyasal parametre düzeylerinin belirlenmesi amacıyla yapıldı. 20 adet brusellozisli ve 15 adet sağlıklı olmak üzere çalışmada toplam 35 adet koyun kullanıldı. Hayvanların Vena jugularis'inden alınan kan antikoagulansız tüplere konuldu. Elde edilen serum örneklerinde haptoglobin (Hp), serum amiloid A (SAA), albümin, total protein (TP) analizleri yapıldı. Brusellozisli koyunlar ile kontrol grubu karşılaştırıldığında Hp, SAA, TP ve globulinin arttığı, albümin düzeyinin ise istatistiksel olarak anlamlı bir şekilde düştüğü belirlendi. Sonuç olarak, çalışmadan elde edilen bulguların brusellozisin tanısına katkı sağlayacağı, Hp ve SAA'nın duyarlı bir indikatör olarak kullanılabileceği ve bu konuda daha detaylı çalışmaların yapılması gerektiği düşünülmektedir.
\end{abstract}

Anahtar Kelimeler: Brusellozis, Haptoglobin, Koyun, Serum Amiloid A.

\section{Determination of Haptoglobin and Serum Amyloid A Levels in Brucella- Infected Sheep}

Abstract: Brucellosis is a chronic zoonotic disease that affects many domestic and wild animals by settling in the genital organs such as the uterus, udder, and testicles, causing a decrease in milk yield, abortion, and infertility. Acute-phase proteins (APP) synthesized by the liver in infections such as inflammation, tissue damage and brucellosis are used in diagnosis, monitoring treatment and evaluation of prognosis. The study was carried out to determine concentrations of some APP and biochemical parameter levels in sheep with brucellosis. For this purpose, a total of 35 sheep, 20 with brucellosis and 15 healthy, were used in the study. The blood collected from the Vena jugularis of the animals was placed in tubes without anticoagulation. Serum samples were used to determine the levels of haptoglobin ( $\mathrm{Hp})$, serum amyloid A (SAA), albumin, and total protein (TP). When the sheep with brucellosis and control group were compared, it was determined that the concentration of $\mathrm{Hp}$, SAA, TP, and globulin increased, and albumin level decreased statistically. As a result, It is thought that the findings obtained from this study will contribute to the diagnosis of brucellosis, $\mathrm{Hp}$, and SAA can be used as a sensitive indicator and more detailed studies should be done on this subject.

Keywords: Brucellosis, Haptoglobin, Serum Amyloid A, Sheep.

\footnotetext{
Kadir Bozukluhan

Kafkas Üniversitesi, Kars Meslek Yüksekokulu, Kars, TÜRKiYE.

e-posta: kbozukluhan@kafkas.edu.tr

* Bu çalışma, Kafkas Üniversitesi, Sağlık Bilimleri Enstitüsü aynı adlı Yüksek Lisans tez çalışmasından özetlenmiştir.
} 
Giriş

B rusellozis; koyun, keçi, sığır, domuz, köpek gibi birçok evcil hayvan ile tilki, dağ keçisi gibi birçok yabani hayvan türünün uterus, meme, testis gibi genital organlarına yerleşerek yavru atma ve infertiliteye neden olan bulaşıcı, kronik ve nekrotik bir retikülohistiyositer hastalıktır (1-3). Bulaşma sindirim sistemi, deri, konjuktiva ve çiftleşme yolu ile olmaktadır (2). Koyunlarda abort, mastitis, eklem şişkinlikleri ve topallık sık görülen belirtiler arasında sayılabilir (4). Alınan marazi maddelerden (atık fetus, süt ve kan vb.) bakteri izolasyonu ve serolojik muayene (Rose Bengal Plate Test (RBPT), Serum Aglütinasyon Test (SAT) vb) ile teşhisi yapılmaktadır $(5,6)$.

Akut faz proteinler (AFP) yangı, doku hasarı, enfeksiyon ve neoplastik büyüme gibi uyarımlara cevap olarak karaciğer tarafından sentezlenen proteinler olarak tanımlanmaktadır (7). Enfeksiyöz ajanları ortadan kaldırmak, organizmayı daha ileri yaralanmalardan korumak gibi fonksiyonları bulunan AFP'lerin teşhis, tedavinin izlenmesi ve prognozun değerlendirilmesinde kullanılabileceği ortaya konulmuştur (8-10). Hastalı̆ın tedavisi ve kontrol programının başarılı olmasında, etkili bir teşhisin önemli olması nedeniyle, ilave biyokimyasal belirteçlerin belirlenmesi hayvanlarda brusellanın kontrolü için gereklidir. Bu nedenle çalışmada brusellozisli koyunların serum AFP düzeylerindeki değişimin belirlenmesi amaçlanmıştır.

\section{MATERYAL ve METOT}

Çalışmaya Kafkas Üniversitesi Hayvan Deneyleri Yerel Etik Kurulu Başkanlığının 2019-164 kodlu etik kurul onayı alındıktan sonra başlandı. Çalışma Kars ili ve ilçelerine ait işletmelerde süt veriminde azalma, abort, infertilite, ateş gibi brusellozis benzeri semptomlara sahip 20 (brusellozisli grup) ve klinik olarak sağlıklı 15 koyun (kontrol grubu) olmak üzere toplamda 35 adet koyunda yapıldı. Brusellozisli ve kontrol grubunu oluşturan koyunların brusella aşı geçmişi bulunmamaktaydı. Koyunların Vena jugularis'inden kan alma tüplerine (antikoagulansız) 5-10 mL kan örnekleri alınarak kısa sürede laboratuvara ulaştırıldı. Kan örneklerinin 3000 rpm, $10 \mathrm{dk}$ santrifüj edildikten sonra elde edilen serumlar ependorf tüplerine aktarıldı ve etiketlenerek analiz yapılıncaya kadar $-20^{\circ} \mathrm{C}$ 'de saklandı.

Serum örneklerinde brusella antikorları, RBPT ve SAT ile araştırıldı. RBPT, SAT Alton ve ark. (11) tarafından bildirilen yönteme göre yapıldı. RBPT'de $(++)$ ve üzeri, SAT'da ise 1:40 ve üzeri dilüsyonlarda aglütinasyona sahip serum örnekleri brusella antikorları yönünden pozitif olarak değerlendirildi.

Serumda; haptoglobin (Hp) Skinner ve ark. (12) bildirdiği yöntemle, serum amiloid A (SAA) (Tridelta Phase range Ireland), serum total protein (TP) düzeyi ve albümin düzeyi (Biolabo, Fransa) ticari test kiti kullanılarak spektrofotometrik (Epoch, Biotek, USA) olarak belirlendi. Çalışmada globulin konsantrasyonları TP değerlerinden albümin değerlerinin çıkarılması ile elde edildi.

\section{İstatistiksel Analiz}

Çalışma verilerinin değerlendirilmesinde IBM SPSS Statistics 20.0 kullanıldı. Analizlerde grupların normal dağılım gösterdiğinden, grupların karşılaştırılmasında student's t-testi kullanıldı.

\section{BULGULAR}

Brusellozisli hayvanların klinik muayenesinde abort, süt veriminde azalma, zayıf veya ölü yavru doğumu, infertilite, topallık tespit edildi. Kontrol grubunu oluşturan koyunlara ait tüm serum örneklerinin RBPT (-) ve SAT (-) olduğu belirlendi. Brusellozisli koyunlara ait tüm serum örneklerinin RBPT (++) ve SAT $(>1 / 160)$ olduğu belirlendi. Brusellozisli koyunlar ile kontrol grubu karşılaştırıldığında Hp, SAA, TP ve globulin $(P<0.001)$ düzeylerinin istatistiksel olarak arttığı, albümin düzeyinin ise $(P<0.01)$ azaldığı belirlendi. 
Tablo 1. Kontrol grubu ve brusellozisli koyunlarda akut faz proteinleri ve bazı biyokimyasal parametrelerin ortalama değerleri ve standart hataları.

Table 1. Mean values and standard errors of acutephase proteins and some biochemical parameters in sheep with brucellosis and control group.

\begin{tabular}{lccc}
\hline $\begin{array}{l}\text { Akut Faz } \\
\text { Proteinleri }\end{array}$ & $\begin{array}{c}\text { Kontrol } \\
\text { Grubu }\end{array}$ & $\begin{array}{c}\text { Brusellozisli } \\
\text { Grup }\end{array}$ & $\mathrm{P}$ \\
\hline $\begin{array}{l}\text { Haptoglobin } \\
\text { (g/L) }\end{array}$ & $0.13 \pm 0.01$ & $0.42 \pm 0.02$ & $\mathrm{P}<0.001$ \\
$\begin{array}{l}\text { Serum } \\
\text { Amiloid A } \\
\text { (mg/mL) }\end{array}$ & $8.34 \pm 0.56$ & $47.81 \pm 1.77$ & $\mathrm{P}<0.001$ \\
$\begin{array}{l}\text { Albümin } \\
\text { (g/dL) }\end{array}$ & $3.18 \pm 0.09$ & $2.77 \pm 0.11$ & $\mathrm{P}<0.01$ \\
$\begin{array}{l}\text { Total Protein } \\
\text { (g/dL) }\end{array}$ & $6.77 \pm 0.30$ & $8.72 \pm 0.28$ & $\mathrm{P}<0.001$ \\
$\begin{array}{l}\text { Globulin } \\
\text { (g/dL) }\end{array}$ & $3.59 \pm 0.35$ & $5.95 \pm 0.31$ & $\mathrm{P}<0.001$ \\
\hline
\end{tabular}

\section{TARTIŞMA ve SONUÇ}

Başta Akdeniz ülkeleri ve Orta Doğu olmak üzere tüm dünyada ve ülkemizde yaygın olarak görülen ve önemli ekonomik kayıplara (abort, infertilite, süt veriminde azalma vb.) neden olan brusellozis, hem hayvan sağlığını hem de insan sağlığını tehdit eden zoonoz bir hastalıktır $(13,14)$.

Kaynaklardaki $(4,14,15)$ bildirimlerle uyumlu olarak brusellozisli koyunların klinik muayenesinde abort, süt veriminde azalma, zayıf veya ölü yavru doğumu ve infertilite belirlendi.

Hastalığın teşhisi alınan marazi maddelerden (atık fetus, süt ve kan vb.) bakteri izolasyonu ve serolojik muayene (RBPT, SAT vb.) ile yapıldı $(5,6,16)$. Çalışmada da hastalığın teşhisinde kaynaklardaki $(5,6,16)$ bildirimlerle uyumlu olarak. RBPT ve SAT testleri kullanılmış olup kontrol grubunu oluşturan koyunlara ait tüm serum örneklerinin RBPT (-) ve SAT (-) olduğu belirlenirken, brusellozisli koyunlarda ise tüm serum örneklerinin RBPT (++) ve SAT (>1/160) olduğu belirlendi.

Akut faz yanıt (AFY) enfeksiyon, doku hasarı, travma gibi nedenlerden dolayı bozulan homeostazisi düzeltmek için organizmanın göstermiş olduğu nonspesifik bir reaksiyondur $(7,8)$. Enfeksiyöz ajanları ortadan kaldırmak, opsonizasyon, organizma için zararlı molekül ve kalıntıları temizlemenin yanı sıra homeostazisi sağlamak için gerekli onarım sürecini aktive etmek gibi fonksiyonları bulunan AFY hastalık sırasında çeşitli hücre ve dokular tarafından salgılanan interlökin-1, interlökin-6 ve tümör nekrozis- $\alpha$ gibi pro veya antienflamatuvar sitokinlerin uyarımı sonucunda oluşmaktadır $(7,17)$. Sitokinler ilk olarak hasarlı dokuda bulunan makrofaj ve monosit gibi mononükleer lökositler tarafından salınarak lokal ve dolaşım aracılığıyla çeşitli doku ve organlara giderek sistemik reaksiyona neden olur $(9,18)$. AFY'nin oluşturduğu sistemik reaksiyonlar arasında ise sitokinler başta olmak üzere mediyatörler (glikokortikoidler, büyüme faktörü vb) aracılığı ile oluşturulan AFP'lerin karaciğerde sentezlenmesi yer almaktadır (19).

Haptoglobin doku hasarı, infeksiyon ve yangıyı takiben konsantrasyonunda belirgin artışlar oluşmaktadır (7). Ruminantlarda doğal ya da deneysel oluşturulan birçok çalışmada, serum $\mathrm{Hp}$ konsantrasyonu arttığı bildirilmiştir (20-24). Ruminantlarda Hp'nin bakteriyel $(10,25)$, viral $(26,27)$, paraziter $(23,28,29)$ hastalıkların tanısında oldukça önemli bir parametre olduğu ve bu hastalıklarda plazma düzeylerinin önemli derecede arttığı bildirilmiştir. Brusella ile ilgili yapılan çalışmalar kısıtlı sayıda olup beşeri hekimlikte Bayraktar ve ark. (30) ile Uluğ ve ark. (31) tarafından yapılan iki ayrı çalışmada brusellozisli insanlarda CRP düzeyinin kontrol grubuna göre istatistiksel olarak önemli olduğu ortaya konulmuştur. Bozukluhan ve ark. (10) brusella ile enfekte sığırlarda yaptıkları bir çalışmada $\mathrm{Hp}$ ve seruloplazmin düzeyinin arttığını, albüminin ise kontrol grubuna göre konsantrasyonunun düştüğünü bildirirken başka bir çalışmada ise $\mathrm{Hp}$ artışı önemsiz olarak bildirilmektedir (32). Shalby ve ark. (33) brusella ile enfekte koyunlarda yaptıkları bir çalışmada da fibrinojenin kan konsantrasyonunun arttığını, Hp konsantrasyonunun ise istatistiksel olarak önemsiz arttığını bildirmişlerdir.

Ruminantlarda önemli diğer bir pozitif AFP olan SAA yangı sırasında karaciğer tarafından 
sentezlenmekle beraber, atlarda ve sığırlarda karaciğer dışında sentezlenen farklı izoformları da bulunmaktadır (19). SAA'nın yangısal olayların şiddetinin belirlenmesinde, prognoz ve uygulanan tedavinin başarısının değerlendirilmesinde kullanılabileceği bildirilmiştir (34). Yapılan çalışmalarda SAA'nın bakteriyel $(35)$, viral $(26,36)$ ve paraziter infeksiyonlarda (29), ketoziste (37) operasyonlardan sonra (38), 3 günden fazla süren açlık durumlarında (39) arttığı ortaya konulmuştur.

Çelik ve ark. (40) brusellozisli insanlarda CRP ve SAA düzeyinin istatistiksel olarak önemli düzeyde yüksek olduğunu bildirmişlerdir. Sharifiyazdia ve ark. (32) brusella ile enfekte sığırlarda yaptıkları bir çalışmada SAA'nın kan düzeyinin istatistiksel olarak önemli derecede arttığı, Hp konsantrayonunun ise istatistiksel olarak önemsiz olduğunu bildirmişlerdir. Çalışmada Hp ve SAA düzeyinin brusella ile enfekte koyunlarda önemli derecede arttığı belirlendi. AFP konsantrasyonundaki artışın nedeni hayvanlarda enfeksiyona bağlı olarak gelişen doku hasarı ve enfeksiyon şiddetiyle ilgili olabileceği düşünülmektedir.

Negatif bir AFP olan albümin, karaciğer tarafından sentezlenip yıkımı büyük oranda böbreklerde gerçekleşmektedir (41). Albümin membran bütünlüğünün ve karaciğer yetmezliğinin belirlenmesinde kullanılan önemli bir parametre olarak kabul edilmektedir $(41,42)$. Onkotik basıncı düzenleme ve endojen amino asitler için kaynak görevi yapma gibi fonksiyonları bulunan albüminin karaciğer, böbrek ve bağırsak hastalıklarında, uzun süren açlık durumunda, AFY sırasında ve malabsorpsiyon sendromunda konsantrasyonunun düştüğü bildirilmektedir $(41,43)$. Kronik veya subakut bakteriyel enfeksiyonlar globulin fraksiyonlarında, özellikle kronik antijenik uyarıma yanıt olarak plazma hücreleri tarafından farklı immunoglobulinlerin üretilmesinden kaynaklanan $\gamma$-globulinlerde artışa neden olabileceği bildirilmektedir (44). Brusellozisli sığırlarda yapılan bir çalışmada (45) TP miktarının değişmediği, albümin miktarının azaldığı buna karşın globulin düzeyinin ise arttığı, ayrıca sığırlarda yapılan başka bir çalışmada (44) ise TP ve globulin düzeyinin istatiksel olarak anlamlı düzeyde arttığı, albümin miktarının ise değişmediği bildirilmiştir. Brusellozisli koyunlarda yaptıkları bir çalışmada TP ve albümin miktarının azaldığı buna karşın globulin düzeyinin ise arttığını bildirirken (46), ayrıca koyunlarda yapılan başka bir çalışmada ise aborttan sonraki 2 ve 4 . haftada TP ve albümin miktarının azaldığı bildirilmiştir (47). Çalışmada TP ve globulin miktarının arttığı, albümin miktarının ise azaldığı belirlenmiştir. Çalışmada belirlenen TP düzeyindeki artış ve albümin düzeyindeki azalış muhtemelen kronik bruselloziste rapor edilen globulin sentezindeki artış ve karaciğer fonksiyon bozukluğu ve/veya oluşan AFY kaynaklı olabileceği düşünülmektedir.

Sonuç olarak, elde edilen bulguların brusellozisin tanısına katkı sağlayacağı, Hp ve SAA'nın duyarlı bir indikatör olarak kullanılabileceği ve bu konuda daha detaylı çalışmaların yapılması gerektiği düşünülmektedir.

\section{Çıkar Çatışması}

Yazarlar, çıkar çatışması olmadığını beyan eder.

\section{KAYNAKLAR}

1. Corbel MJ., 2006. Brucellosis in Humans and Animals. World Health Organization, Food and Agriculture Organization of the United Nations, World Organisation for Animal Health, Switzerland.

2. Nicoletti P., 2010. Brucellosis: Past, present and future. Contributions, section of medical science. Prilozi, 31, 21-32.

3. Hancı İ., Gürcan S., Sönmez A., 2016. Sığır ve koyunlarda eş zamanlı brusella ve şap aşısı uygulamalarının antikor düzeylerine etkisi. Etlik Vet Mikrobiyol Derg, 27, 27-37.

4. Xavier MN., Paixao TA., Hartigh AB Den., Tsolis RM., Santos RL., 2010. Pathogenesis of Brucella spp. Open Vet Sci J, 4, 109-118.

5. Olsen S., Bellaire B., 2013. Brucella. In "Veterinary Microbiology", Eds., DS McVey, M Kennedy, MM Chengappa, 3rd ed., 127-133, 
Wiley Blackwell, USA.

6. Genç O., Serdar G., 2019. Bruselloz tanısı ve epidemiyolojik çalışmalarda moleküler yöntemlerin kullanılması. Erciyes Univ Vet Fak Derg, 16, 68-72.

7. Tothova C., Nagy O., Kovac G., 2014. Acute phase proteins and their use in the diagnosis of diseases in ruminants. Vet Med, 59, 163-180.

8. Ceciliani F., Ceron JJ., Eckersall PD., Sauerwein H., 2012. Acute phase proteins in ruminants. J Proteomics, 75, 4207-4231.

9. Sevgisunar NS., Şahinduran Ş., 2014. Hayvanlarda akut faz proteinleri, kullanım amaçları ve klinik önemi. MAKÜ Sağ Bil Enst Derg, 2, 50-72.

10. Bozukluhan K., Merhan O., Büyük F., Çelebi Ö., Gökçe G., 2016. Brusellozisli sığırlarda bazı akut faz proteinlerinin düzeyinin saptanması. Ankara Üniv Vet Fak Derg, 63, 13-16.

11. Alton GG., Jones LM., Angus RD., Verger JM., 1988. Techniques for the brucellosis laboratory. 190, INRA Publications, Paris, France.

12. Skinner JG., Brown RAL., Roberts L., 1991. Bovine haptoglobin response in clinically defined field conditions. Vet Rec, 128, 147-149.

13. Selem MN., Boyle SM., Sriranganathan N., 2009. Review Brucellosis: A reemerging zoonosis. Vet Microbiol, 140, 392-398.

14. Otlu S., 2012. Hayvanlarda Bruselloz. Turkiye Klinikleri J Inf Dis-Special Topics, 5, 99-106.

15. Kuyucuoğlu Y., 2011. Brusella hastalığı. Kocatepe Vet J, 4, 57-64.

16. Poester FP., Nielsen K., Samartino LE., Ling Yu W., 2010. Diagnosis of Brucellosis. Open Vet J, 4, 46-60.

17. Eckersall PD., Bell R., 2010. Acute phase proteins: Biomarkers of infection and inflammation in veterinary medicine. Vet J, 185, 23-27.

18. Eckersall PD., 2000. Recent advances and future prospects for the use of acute phase proteins as markers of disease in animals. Revue Med Vet, 151, 577-584.
19. Petersen HH., Nielsen JP., Heegaard PM., 2004. Application of acute phase protein measurements in veterinary clinical chemistry. Vet Res, 35, 163-187.

20. Nazifi S., Rezakhani A., Koohimoghadam M., Ansari-Lari M., Esmailnezhad Z., 2008. Evaluation of serum haptoglobin in clinically healthy cattle and cattle with inflammatory diseases in shiraz, a tropical area in southern Iran. Bulg J Vet Med, 11, 95-101.

21. Bayyit E., Merhan O., 2020. Normal ve güç doğum yapan ineklerde bazı akut faz proteinlerinin ve oksidatif stres düzeyinin belirlenmesi. Atatürk Univ Vet Bil Derg, 15, 145150.

22. Merhan O., Özcan A., Atakişi E., Öğün M., Kükürt A., 2016. The effect of $\beta$-carotene on acute phase response in diethylnitrosamine given rabbits. Kafkas Univ Vet Fak Derg, 22, 533-537.

23. Bozukluhan K., Merhan O., Özcan A., Gökçe Hi., Gökçe G., 2017. Toxocara vitulorum ile doğal enfekte buzağılarda serum haptoglobin düzeyi, oksidatif belirteçler ve bazı biyokimyasal parametrelerin düzeyinin belirlenmesi. Ankara Üniv Vet Fak Derg, 64, 75-79.

24. Kızıl Ö., Gazioğlu A., Balıkcı E., 2017. Akut ruminal laktik asidozisli koyunlarda akut faz protein yanıt. Fırat Üniv Sağıık Bil Vet Derg, 31, 97-100.

25. Merhan O., Bozukluhan K., Çelebi Ö., Öğün M., Atakişi E., Büyük F., 2017. Levels of acute phase protein and some biochemical parameter in cattle infected with Mycobacterium bovis. Erciyes Univ Vet Fak Derg, 14, 101-105.

26. Merhan O., Bozukluhan K., Kızıltepe Ş., Gökçe Hi., 2017. Investigation of levels of haptoglobin, serum amyloid $A$, ceruloplasmin and albumin in cattle with foot and mouth disease. Isr J Vet Med, 72, 14-17.

27. Bozukluhan K., Merhan O., Gökçe Hi.,, Öğün M., Atakişi E., Kızıltepe Ş., Gökçe G., 2018. Determination of some acute phase proteins, biochemical parameters and oxidative stress in sheep with naturally infected sheeppox virus. 
Kafkas Univ Vet Fak Derg, 24, 437-441.

28. Ulutaş PA., Voyvoda H., Ulutaş B., Aypak S., 2008.

Miks enfeksiyonlu keçilerde haptoglobin, serum amiloid A ve seruloplazmin konsantrasyonları. Türkiye Parazitol Derg, 32, 229-233.

29. Merhan O., Bozukluhan K., Gökçe Hi.., 2017. Acute phase proteins and biochemical and oxidative stress parameters in Hypoderma spp infested cattle. J Hellenic Vet Med Soc, 68, 535540.

30. Bayraktar M., Bayraktar N., Bayındır Y., Durmaz R., 2005. Brusellozlu hastalarda serum $C$ reaktif protein, demir ve ferritin düzeylerinin tanı ve izlemdeki değeri. ANKEM Derg, 19, 61-63.

31. Uluğ M., Uluğ NC., Selek Ş., 2010. Akut brusellozlu hastalarda akut faz reaktanların düzeyi. Klimik Dergisi, 23, 48-50.

32. Sharifiyazdia H., Nazifi S., Nikseresht K., Shahriari R., 2012. Evalution of serum amyloid $A$ and haptoglobin in dairy cows naturally infected with brucellosis. J Bacteriol Parasitol, 3, 1-4.

33. Shalby NA., Abo El-Maaty AM., Ali AH., Elgioushy M., 2020. Acute phase biomarkers, oxidants, antioxidants and trace minerals of mobile sheep flocks naturally infected with brucellosis. Bulg J Vet Med, (online first).

34. Batırel A., Gençer S., Özer S., 2003. Enfeksiyon göstergesi olarak akut faz reaktanları: C-reaktif protein (CRP) ve serum amiloid A (SAA). J Kartal Tr, 14, 220-224.

35. Horadagoda A., Eckersall PD., Hodgson JC., Gibbs HA., Moon GM., 1994. Immediate responses in serum tnf $\alpha$ and acute phase protein concentrations to infection with Pasteurella haemolytica A1 in calves. Res Vet Sci, 57, 129132.

36. Ganheim C., Hulten C., Carlsson U., Kindahl H., Niskanen R., Waller KP., 2003. The acute phase response in calves experimentally infected with bovine viral diarrhoea virus and/or Manheimia haemolytica. J Vet Med Ser B, 50, 183-190.

37. Karreman HJ., Wentink GH., Wensing T., 2000. Using serum amyloid a to screen dairy cows for sub- clinical inflammation. Vet Quart, 22, 175178.

38. Bozukluhan K., Gökçe Hi.,, 2007. Retikuloperitonitis travmatika ve retikuloperikarditis travmatika'lı sığırlarda bazı akut faz proteinlerin araştırılması. Erciyes Univ Vet Fak Derg, 4, 107-113.

39. Katoh N., Oikawa S., Oohashi T., Takahashi Y., Itoh F., 2002. Decreases of apolipoprotein B-100 and A-1 concentrations and induction of haptoglobin and serum amyloid $A$ in non-fed calves. J Vet Med Sci, 64, 51-55.

40. Çelik VK., Sarı İ., Bakır S., Engin A., Bakır D., Sarı M., Poyraz Ö., Yıldız G., 2011. Erythrocyte sedimentation rate, serum amyloid $A$ and Creactive protein levels in patients with acute brucellosis. Pak J Med Sci, 27, 823-826.

41. Kaneko JJ., Harvey JW., Bruss ML., 2008. Clinical Biochemistry of Domestic Animals. 6th ed., 364390, Academic Press, New York.

42. Cray C., Zaias J., Altman NH., 2009. Acute phase response in animals: A review. Comp Med, 59, 517-526.

43. Gruys E., Toussaint MJM., Niewald TA., 2005. Acute phase reaction and acute phase proteins. J Zhejiang Univ Sci, 11, 1045-1056.

44. Elazab MFA., 2015. Evalution of serum enzyme activities and protein fractions in brucellainfected cows. Turk J Vet Anim Sci, 39, 480-484.

45. Nath R., Das S., Sarma S., Devi M., 2014. Comparison of blood profiles between healthy and brucella affected cattle. Vet World, 7, 668670.

46. Kumar AV., Srikanth NR., Naresh G., Vidya B. 2015. Assessment and comparison of serum biochemical parameters of Brucella infected and healthy ewes. J Livestock Sci, 6, 100-103.

47. Hashem MA., El-Mandrawy SA, El-Diasty MM., Zidan AZ., 2020. Hematological, biochemical and immunological studies on brucellosis in cows and ewes in Dakahlia and Damietta Governorates, Egypt. Zag Vet J, 48, 23-35. 